\title{
Review
}

\section{Red Kant: Aesthetics, Marxism and the third critique}

\author{
Michael Wayne \\ Bloomsbury, London, 2014, 208 pp., ISBN: 978-1472505118 \\ Contemporary Political Theory (2016) 15, e29-e32. doi:10.1057/cpt.2015.33; \\ published online 30 June 2015
}

As the title suggests, Michael Wayne argues that Kant can be viewed as a forerunner to Marx. This is based on the view that the Critique of Judgement marks a productive break from Kant's previous critical work. Wayne's aim is not to argue that Kant himself would be sympathetic to such a reading, of course. This is not a work that fits within the Cambridge School of history of philosophy. It does not try to capture what Kant meant by analysing historical influences and frameworks. Instead, it is an interesting reworking of Kant's conceptual framework from the Critique of Judgement that draws in part on Adorno but that is also in conversation with a number of contemporary theorists: Rancière, Deleuze, Bourdieu, Eagleton and Shaviro. Oddly both Arendt's and Lyotard's response to her work is omitted. I will discuss Arendt's political reading of Kant's Critique of Judgement and its relevance to Wayne's position below.

Wayne starts by setting out the argument that the Critique of Judgement allows a shift from a reified view of concepts in Kant's earlier work to a framework in which the imagination is no longer subordinate to understanding, as described in the experience of the beautiful. I have selected some of Wayne's arguments regarding: the phenomenal/noumenal split, the beautiful and the sublime to give an overview of the type of arguments in the book. I will start with the phenomenal/ noumenal divide.

Kant divides the world into two: the phenomenal, which is the way that the world appears to us as we perceive and structure it, and the noumenal, 'things in themselves', which we cannot know but can only think. Wayne maps the phenomenal/noumenal split onto Marx's view of ideology, which divides the world into the appearance of things (now corresponding to Kant's phenomenal realm) and how they are 'in themselves' (now mapped onto the Kantian noumenal realm). For example, for Marx, capitalist society may appear to be a just society because individuals have rights and formal equality but in reality it is a society based on workers' exploitation and subordination. 
Although, Kant's epistemology and Marx's conception of ideology can both be understood as having a division between appearance and reality, one obvious difference is that Kant's epistemology blocks any knowledge of 'things in themselves'. In contrast, Marx has access to and explains the political reality behind ideology. Framed in Kantian terms, Marx appears as a romantic hero who can lift the veil of Isis to see into the noumenal realm of things as they are in themselves. However, as no doubt Wayne is aware, the brutal reality of capitalism is known, particularly to those who suffer as a result. Wayne's move therefore alters Kantian epistemology, effectively ridding it of the noumenal. This is a provocative re-reading because of the way that Kant can then be positioned a master of suspicion before Marx, Nietzsche and Freud.

Turning to the beautiful, in Kant's Critique of Judgement he describes a harmonious play between the faculties of imagination and understanding. In the earlier Critique of Pure Reason, he argued that, in order for a representation of an object to be produced in the mind, there is an interaction between the imagination (which produces a synthesis of the manifold of intuitions) and the understanding (which unites this under a concept). In Section 9 of the Critique of Judgement, Kant describes our experience of the beautiful as resulting from these two faculties freewheeling rather than settling upon one concept. (Think of someone looking at an ink blot and envisaging it as different objects, now a dragon, now a dog, but without settling on any particular classification.)

Importantly, as a result of this harmonious play of the faculties, Kant argues that we can demand that others share our judgement that an object is beautiful, even though we cannot employ a rule that this is the case. In other words, this communication of what is beautiful occurs because we all have the same faculties that act in the same way. Arendt (1989) famously drew upon this image of communication of the beautiful to argue that the Critique of Judgement is not simply a philosophy of aesthetics but also a political text. Although, Wayne does not discuss Arendt at all, he follows her to argue that Kant's Critique of Judgement opens up inter-subjectivity and communication as a result of the way in which we demand that others share our view of the beautiful.

In his discussion of Rancière, Wayne states that he agrees with the 'bourgeois left wing intelligentsia's' analysis of Kant 'to a degree', but that he and they 'part company on how to characterize what is going on within the aesthetic as a mode of disruption' (p. 108). This raises questions about art as a communicative experience, evocative of a social bond, and how it can be viewed in ways that are neither individualised nor separate from historical conditions.

Turning to the sublime, in the experience evoked by sublime art, in contrast with the beautiful, nature is portrayed as potentially threatening. This also lies in contrast with the beautiful in nature, which appears 'as if' it were made for us. The experience of the sublime involves a mixture of threat (or displeasure) followed by release, involving the conflicting interaction of the faculties of imagination and reason. 
In Kant's Critique of Judgement, he describes two different types of sublime experience. In the dynamic sublime, the viewer is threatened by the might of nature, such as the stormy violent sea. This is followed by the knowledge that - as creatures of reason - 'we' would be able to stand up to such a threat and behave morally. Similarly, the experience of the mathematical sublime involves first discomfort and then release: a failure of the imagination to produce an image of something extremely large (such as the Alps) followed by the recognition that this was attempted at the behest of reason. Interestingly, as a film theorist Wayne resists the lure of Alice in Wonderland beloved by continental philosophers and uses films such as The Incredible Shrinking Man to demonstrated the sublime. He notes that everyday objects become both huge (evoking the experience of the mathematical sublime) and threatening (dynamic sublime) when we envisage ourselves in a familiar environment after having shrunk in size. The films discussed appear as useful examples but the work is led by the theoretical position. In common with Arendt, he emphasises the beautiful rather than sublime in his political reading of the Critique of Judgement.

I would add that in Kant's Critique of Judgement 'men of trade' and certain races were not viewed as being able to stand up to the threat in order to experience the sublime. Similarly, Kant argues that women should not do so and that standing up to the might of nature involves courage - a masculine virtue. Given these exceptions, it is useful to compare Wayne's reworking of Kant's Critique of Judgement from a Marxist position with feminist reworkings of this text. From a Marxist position subjects are wrongly treated as objects and the solution is to treat them as subjects. However, recent feminist analysis problematises the subject/ object split from the position of women, who are historically not quite classified as either subject or object. In describing the sublime experience, Kant envisages a subject who is able to stand up to the might of nature, viewed in terms of a divide between himself (white, male and not working class) and what is external to him. In contrast, Battersby $(1998,2007)$ provides a detailed reworking of Kant's conceptual framework in order to think of a subject who is not constituted by such a split (between himself and the outside) but who emerges as a result of relationality over time.

Wayne does not explore the relationship between Marxist and feminist reworkings of Kant's aesthetics. To the extent that there is a discussion of the relationship between subject and object, he is interested in freeing up concepts of the understanding to bring in social and historical relations. This fits more with Adorno, whose work is usefully discussed, and with the idea that autonomous art has the power to shift the conceptual framework of the subject.

The argument that there is a productive divide between Kant's early work and the Critique of Judgment is convincing. I have only drawn out a few - albeit I think representative - ways in which Kant's framework is reworked in what is an interesting and provocative area of thought. 


\section{References}

Arendt, H. (1989) Lectures on Kant's Political Philosophy. In: R. Beiner (ed.). Chicago: University of Chicago Press.

Battersby, C. (1998) The Phenomenal Woman: Feminist Metaphysics and the Patterns of Identity. London: Routledge.

Battersby, C. (2007) The Sublime, Terror and Human Difference. London: Routledge.

Janice Richardson

Monash University, Melbourne, Victoria 3800, Australia. 